\title{
Major Depression and Psoriasis: A Psychodermatological Phenomenon
}

\author{
Hassaan Tohid $^{\text {a }}$ Daniyal Aleem $^{b}$ Chantal Jackson $^{c}$ \\ ${ }^{a}$ Center for Mind and Brain, University of California, Davis, Davis, Calif., ${ }^{b}$ Department of Neurology, \\ University of California, San Diego, San Diego, Calif., and ' Dermatology, University of California, San Francisco, \\ San Francisco, Calif., USA
}

\section{Key Words}

Depression psoriasis · Psychodermatology .

Neurodermatology · Psoriasis and major depression .

Inflammation depression · Inflammation psoriasis

\begin{abstract}
Objective: The aim of this paper was to highlight the mechanisms involved and the relationship between depression and psoriasis. Method: A comprehensive literature search was performed in various databases, and finally 88 studies were deemed relevant. Results: A significant link was found between depression and psoriasis, primarily through immune mechanisms related but not limited to the actions of inflammatory cytokines such as tumor necrosis factor- $a$, interleukin 1 (IL-1), IL-2, IL-10, interferon- $\gamma$, IL-1 $\beta$, prostaglan$\operatorname{din}$ E2, C-reactive protein, IL-6, and IL-8. Conclusion: Various neuroimmunological studies point towards the notion that depression and psoriasis are associated with each other. Melatonin has also been found to be associated with both conditions. A possibility exists that both conditions can cause each other due to the possible bidirectional relationship of psoriasis and major depression. However, if this is the case, then why all depressed patients fail to develop psoriasis and why all psoriatic patients fail to develop depression remains a question unanswered. We believe that future studies will unmask this mystery.

(c) 2016 S. Karger AG, Basel
\end{abstract}

\section{Introduction}

Psychosomatic medicine is an interdisciplinary branch of medicine which studies the effects of social, psychological, and behavioral factors on bodily processes, their relationship with one another, and quality of life [1]. This article addresses the topic of psychodermatology, which is a subbranch of psychosomatics [2].

A psychodermatological disorder is a condition that involves an interaction between the nervous and the integumentary system. Psychodermatological disorders fall into three categories: psychophysiological disorders, primary psychiatric disorders, and secondary psychiatric disorders [3].

In this paper we attempt to further explore a psychodermatology topic: 'the relationship of major depression with psoriasis'. Currently, not much is known about this association other than specific research which emphasizes that psoriasis leads to depression. However, in this article we attempt to explore a different aspect of this association, i.e. 'whether major depression causes enough skin damage which ultimately leads to psoriasis? Or are there any inflammatory markers or cytokines released during depression that can trigger the onset of psoriasis?' Significant research has been done on depression and psoriasis in the past, and on many of their respective comorbidities related to the field of psychodermatology.

\section{KARGER}

E-Mail karger@karger.com

www.karger.com/spp
(C) 2016 S. Karger AG, Basel

$1660-5527 / 16 / 0294-0220 \$ 39.50 / 0$
Dr. Hassaan Tohid

3533 Valley View Court

Fairfield, CA 94534 (USA)

E-Mail hassaantohid@ hotmail.com 
However, little has been done regarding their bidirectional nature, and this paper aims to change that.

Psoriasis, or psoriasis vulgaris, is a long-lasting, and often chronic, immune-mediated inflammatory disease that is typically characterized by the appearance of patches of abnormal skin [4]. These patches are well-defined red, itchy, scaly plaques of a silver/white fashion and range in severity from a minute localization to full body coverage [5]. Psoriasis disease phenotypes can potentially weaken with age or increase in severity, depending on external factors [6]. However, psoriasis is currently not completely understood as considerable variance exists amongst disease phenotype and genotype amongst individuals. Generally speaking, psoriasis is defined as a genetic disease whose onset is due to certain environmental factors, including family history, physical or emotional stress, poor standards of living, and withdrawal of systemic corticosteroids $[7,8]$. It is believed to be associated with $2-4 \%$ of the population in western countries, with a higher prevalence amongst Caucasians [9].

Contrary to popular belief, psoriasis is not just a physical skin problem which leads to depression; it could actually be caused by major depression due to an immunological and a neurochemical phenomenon [10]. The pathophysiology of depression has long been in debate, and its association with various neurochemicals has been found. It is a common belief that depression causes behavioral problems. However, depression can also lead to physical pathology on the skin and other organs such as the heart [11-15]. This subject is widely studied in psychosomatics. This comprehensive review highlights the pathophysiological association between major depression and psoriasis.

\section{Depression and Psoriasis: A Psychodermatological Association}

Psoriasis, which is a long-lasting immune-mediated skin disease characterized by the emergence of red, silver scaly patches of abnormal skin that range in severity from a minute localization to full body coverage, is found to be associated with clinical depression commonly known as major depression through an immunological phenomenon [10].

Many studies have shown the possibility of a relationship between common forms of psoriasis and major depressive disorder. In a study by Akay et al. [16], patients with psoriasis were found to have extremely high Beck Depression scores, which correlated with Psoriasis Area and Severity Index scores, and were considered to be at a higher depression score than the non-psoriasis-afflicted controls, similar to an experiment done by Esposito et al. [17] where depressive symptomology was observed in $62 \%$ of psoriasis patients involved in the study of 2,391 patients. In fact in two studies done by Gupta et al. [18, 19], an increase in stress and depressive symptoms were found to have a significant statistical correlation with an increase in psoriasis flare-ups and pruritus severity along with a more clinically disfiguring disease. In addition, studies have shown that a decrease in depression/depressive symptoms due to medication or therapy is associated with a decrease in psoriasis severity and vice versa [2026]. The question now remains: is this correlation merely due to the negative psychological effects inherent in any clearly discernible skin disorder, or any disorder in general, such as social anxiety, low self-esteem, shame/embarrassment etc., or is there an underlying pathophysiological mechanism involved? This study explores the different mechanisms that have been shown in relation to the aforementioned conditions.

\section{Immunological Changes in Psoriasis}

The pathophysiology of psoriasis has been studied in depth, and inflammatory and immunological associations have been found. Psoriasis has been found to be due to the occurrence of macrophages, $\mathrm{T}$ cells, and dendritic cells migrating away from the dermis and towards the epidermis $[27,28]$ and subsequently releasing inflammatory cytokines such as tumor necrosis factor- $\alpha$, (TNF- $\alpha$ ), interleukin $1 \beta$ (IL-1 $\beta$ ), and IL-6, IL-22, or a type- 1 cytokine profile (IL- 2 , interferon- $\gamma$, IFN- $\gamma$, and TNF- $\alpha$ ). According to another notion, psoriasis involves a defect in regulatory $\mathrm{T}$ cells and in the regulatory cytokine IL-10. These chemical messages from dendritic cells and $\mathrm{T}$ cells trigger keratinocytes to release cytokines (IL-1, IL-6, and TNF- $\alpha$ ), which signal downstream inflammatory cells to cause more inflammation [29].

Dendritic cells bring the use of the innate immune system and adaptive immune system together. These systems are activated in psoriatic lesions [30], consequently resulting in inflammation, psoriatic lesions, and increased keratinocyte production [31]. Skin in psoriatic patients goes through excessive cell growth and production, which is probably more than that observed in wound healing [32], and is replaced rapidly in 3-5 days in psoriatic patients compared to the standard 28-30 days, without release through shedding [33]. Theoretically speaking, this 
is all assumed to be due to a mutation in the regulatory cytokine IL-10 or defects in surrounding regulatory $\mathrm{T}$ cells; however, the inflammatory pathway itself is not unique [29]. A neurotrophin known as brain-derived neurotrophic factor (BDNF), which plays an integral role in neuroplasticity and mental disorders, was found to be associated with psoriasis by Brunoni et al. [34]. The authors calculated the blood BDNF levels instead of brain $\mathrm{BDNF}$ levels and found that these BDNF levels are reduced in depression and psoriasis. Abnormal IL-17 expression has also been observed in psoriatic patients with therapeutic inhibition showing success in reducing disease severity $[35,36]$. Furthermore, as has been discussed above, inflammatory cytokines like TNF- $\alpha$, IFN- $\gamma$, and other type-1 cytokines play a crucial part in the pathophysiology of psoriasis [26].

\section{Systemic Immunological Changes in Major Depression}

On the other hand, major depression along with inflammatory markers have been studied in depth by many authors. A study by Wong et al. [37] also highlighted that immune system dysregulation occurs in major depressive disorder along with increased levels of CXCL10/IP-10, which decreased in response to antidepressants, suggesting type-1 T-cell activity. Another study by Miller et al. [38] found that patients with major depression had augmented levels of peripheral blood inflammatory biomarkers, including inflammatory cytokines, which interacted with the pathophysiological domains involved in depression, including neurotransmitter metabolism, neuroendocrine function, and neural plasticity. They further activated inflammatory pathways which increased oxidative and nitrosative stress which, in turn, stimulated inflammatory signaling molecules such as nuclear factor kappa B through sympathetic nervous system outflow pathways $[38,39]$. Moreover, evidence exists that antidepressant therapy is associated with reduced inflammatory responses [40]. It has also been observed that in certain cases chronic inflammation is a prevalent component of mood disorders, including depression [41]. Elevation in the concentration of proinflammatory cytokines, including prostaglandin E2, C-reactive protein (CRP), TNF- $\alpha$, IL-1 $\beta$, IL-2, and IL-6, has also been connected with major depressive disorder, and there may potentially exist a dose response with a higher concentration of inflammatory markers linked to more severe depressive morbidity $[41,42]$. Additionally, proinflammatory cytokines have been shown to induce sickness behavior and depressive symptoms in dogs, and this may also occur in humans [43]. Serotonin transporter availability and function is increased by proinflammatory cytokines, thus triggering depression in rodent models. Krishnadas et al. [10] proposed that increased circulating inflammatory cytokine concentrations, especially of TNF- $\alpha$, could be linked with greater 5-HTT availability, and that TNF- $\alpha$ inhibition with etanercept (soluble TNF receptor:Fc) would possibly decrease the 5-HTT availability.

According to a study, high levels of proinflammatory cytokines (TNF- $\alpha$ and IL-6) have been found in depressed patients [44]. This is usually independent of any preexisting chronic inflammatory disorders. Inflammation in depression has been studied in depth by various other authors. They discussed increased proinflammatory cytokines, increased acute-phase proteins, and increased expression of chemokines and adhesion molecules in depressive patients [45-61]. In relation to depressed patients, increased levels of IL-1- $\beta$ and TNF- $\alpha$ have also been found in the peripheral blood circulation and in the cerebrospinal fluid [62-65]. In addition, it has also been observed that the therapeutic administration of the cytokine IFN- $\alpha$ causes depression in up to half of depressive patients, which provides further evidence about the role of inflammation in depression [66].

\section{Bidirectional Inflammatory and Neurochemical Phenomenon}

The above-mentioned paragraphs denote that many inflammatory markers and cytokines which are released during depression are also released during psoriasis. Therefore, we believe a possible connection between the two conditions exists. This notion is also supported by many other authors in various research articles [67]. Furthermore, genetic variations of the serotonergic system have been described, including a variable number of tandem repeat polymorphisms in intron 2 of the 5-HTT gene and polymorphism of serotonin receptors, which could play a role in the pathogenesis of psoriasis and depressive symptoms in psoriasis patients [67].

Proof of any sort of direct positive or negative relationship between psoriasis and depression and its directionality in it is extremely difficult to attain, yet despite that evidence does exist supporting the theory that the relationship is bidirectional. Psoriasis is known to have a number of different comorbidities, as shown in a study by $\mathrm{Ni}$ and Chiu [68], such as cardiovascular disease, obesity, diabe- 
tes, hypertension, dyslipidemia, metabolic syndrome, nonalcoholic fatty liver disease, cancer, anxiety and depression, and inflammatory bowel disease. Inflammatory bowel disease was found to be at a higher prevalence in psoriasis patients compared to the general population. Additionally, the administration of proinflammatory cytokines in certain of the above therapies was linked to psoriasis morbidity. A similar study by Schiepers et al. [69] found that the administration of proinflammatory cytokines in animals induced 'sickness behavior' or a pattern of behavioral abnormalities closely associated with the behavioral symptoms of depressive disorder in humans. In theory, an increase in proinflammatory cytokines such as those previously mentioned to be associated with psoriasis - that lead to inflammation and psoriatic lesions observed in psoriasis patients - can cause hypothalamic-pituitaryadrenal (HPA) axis hyperactivity observed in major depressive disorder and disturb the negative feedback inhibition of circulating corticosteroids on the said axis as well as lower serotonergic (5-HT) neurotransmitter levels. This can activate signal cascades that lead to what is considered depressive symptomology, including peripheral cell-mediated activation, inflammation and induction of oxidative and nitrosative stress pathways, central microglial activation, decreased neurogenesis, increased apoptosis, and melancholy, anxiety, and fatigue and somatic symptoms $[69,70]$. On the flip side, major depressive disorder can increase the concentration of inflammatory cytokines present systemically, which can lead to or increase psoriasis severity, and studies have also shown that depressive events generally predate psoriasis onset [71-73]. In addition, some other research studies also described that the risk for having psoriasis increases significantly in patients who have moderate to severe depression [74-76]. Psychological stress has also been found to cause phenotypic changes in patients, potentially triggering psoriasis, and to have an association with CRP levels in women with psoriasis [77, 78].

In addition to Inflammation, melatonin levels can also relate depression with psoriasis. Depression has been found to lead to diminished melatonin secretion in patients compared to unafflicted patients following a normal circadian rhythm. Although primarily involved in regulating sleep cycles, melatonin has been found to have an additional influence on the immune system, specifically on levels of TNF- $\alpha$, IL- 6 , and IL- 8 along with other products of the inflammation cascade [79-82]. Similarly, melatonin levels were found to be abnormally low in patients with skin disorders, including psoriasis [83]. Furthermore, a reduction in depressive state was found to

Psychopathophysiology of DepressionInduced Psoriasis and Vice Versa normalize melatonin levels and cause a regression of psoriatic lesions [80]. Phototherapy may be an effective strategy in regulating melatonin levels, decreasing psoriatic inflammation, and lessening depressive symptoms that further aggravate psoriasis [84].

Increased levels of proinflammatory cytokines, especially TNF- $\alpha$ and IL-6, are seen in depressed patients. In a study by Golpour et al. [85], 60\% of psoriatic patients believed stress was a causal factor for their psoriasis, and a significant association has been found for patients with psoriasis with clinical depression, clinical anxiety, and suicidal ideation $[85,86]$. Research evidence suggests that TNF- $\alpha$ blockers, used in the treatment of psoriasis, could be helpful in reducing depressive symptoms for patients with psoriasis and other chronic inflammatory conditions [44]. Furthermore, an interesting study involving genes was conducted between depression and psoriasis by Demirhan et al. [87]. The authors used cell cultivation and conventional G-banding. They observed mostly numerical changes; chromosomes $8,22,21,15, \mathrm{X}$, and $\mathrm{Y}$ were affected mostly, with 8 being the most commonly involved chromosome. Structural changes comprised of duplications, deletions, translocations, and breaks, with a focus on loci on $\operatorname{del}(1)(\mathrm{q} 12-\mathrm{q} 23), \operatorname{del}(1)(\mathrm{q} 21.1-\mathrm{q} 24)$, $\operatorname{del}(1)(\mathrm{q} 21.1-\mathrm{q} 23), \quad \operatorname{del}(10)(\mathrm{p} 11.2-\mathrm{pter}), \quad \operatorname{der}(2) \mathrm{t}(2 ; 4)$ (p25;p12), t(2;22)(p14;p13), t(19;Y)?, and dup(10)(q26). They thought that the susceptibility genes of major depression or psoriasis could be located on these loci. Numerical sex chromosomal analysis included 4 with 45 , X (5.8\%), 3 with 47,XXY (4.3\%), and 4 with structural chromosome X (5.8\%): $\operatorname{del}(\mathrm{X})(\mathrm{q} 13), \operatorname{del}(\mathrm{X})(\mathrm{p} 11-\mathrm{pter}), \operatorname{del}(\mathrm{X})$ (q21.3), and $\operatorname{inv}(\mathrm{Y})(\mathrm{q} 11.2)$. They also performed an immunological study. The results of the immunological study demonstrated that the percentage of $\mathrm{CD} 2+, \mathrm{CD} 4+$, and CD8+ lymphocytes of the father were remarkably raised, while on the other hand CD4+ lymphocytes were reduced in the mother, in comparison to the controls. In the son, the percentage of CD8+ lymphocytes was higher, whereas the CD4 level was reduced. The CD4/CD8 ratio of the father and the son was found to be remarkably high. The results may suggest that major depression and psoriasis have a high impact on both genetic and immunological parameters (tables 1, 2).

\section{Conclusion}

Although extensive research has not been conducted on the subject, there is substantial evidence that a relationship between depression and psoriasis exists and that 
Table 1. Details of some of the studies from the review

\begin{tabular}{|c|c|c|c|c|c|c|}
\hline $\begin{array}{l}\text { Author/ } \\
\text { publication } \\
\text { year }\end{array}$ & Country & $\begin{array}{l}\text { Study } \\
\text { design }\end{array}$ & Population & Sample size & $\begin{array}{l}\text { Diagnostic } \\
\text { criteria }\end{array}$ & Main points \\
\hline $\begin{array}{l}\text { Chong et al. } \\
\text { [7], } 2013\end{array}$ & Australia & Review & N/A & N/A & N/A & $\begin{array}{l}\text { Psoriasis is a common chronic inflammatory skin condition in which } \\
\text { patients suffer from mild-to-chronic plaque skin plaques; the disease } \\
\text { manifests through an excessive inflammatory response in the skin due } \\
\text { to complex interactions between different genetic and environmental } \\
\text { factors; psoriasis can affect the physical, emotional, and psychosocial } \\
\text { well-being of patients, and currently there is no cure with treatments } \\
\text { focusing primarily on the use of anti-inflammatory agents to control } \\
\text { disease symptoms }\end{array}$ \\
\hline
\end{tabular}

\begin{tabular}{|c|c|c|c|c|c|c|}
\hline $\begin{array}{l}\text { Huerta et al. } \\
{[8], 2007}\end{array}$ & UK & $\begin{array}{l}\text { Cross-sectional } \\
\text { study }\end{array}$ & $\begin{array}{l}\text { The study population } \\
\text { comprised patients } \\
\text { receiving a first-ever } \\
\text { diagnosis of psoriasis } \\
\text { between January } 1,1996 \\
\text { and December } 31,1997 \\
\text { and who were free of } \\
\text { cancer }\end{array}$ & $\begin{array}{l}3,994 \text { cases } \\
\text { of psoriasis } \\
\text { and a random } \\
\text { sample of } \\
10,000 \\
\text { controls }\end{array}$ & $\begin{array}{l}\text { Un- } \\
\text { specified }\end{array}$ & $\begin{array}{l}\text { The incidence rate of psoriasis was } 14 \text { per } 10,000 \text { person-years; } \\
\text { patients with antecedents of skin disorders and skin infection within } \\
\text { the last year carried the highest risk of developing psoriasis (OR, 3.6, } \\
95 \% \text { CI, } 3.2-4.1 \text { and OR, } 2.1,95 \% \text { CI, } 1.8-2.4 \text {, respectively); also, } \\
\text { smoking was found to be an independent risk factors for psoriasis } \\
\text { (OR, } 1.4,95 \% \text { CI, } 1.3 \text { - } 1.6 \text { ); we did not find an association between } \\
\text { risk of psoriasis and antecedents of stress, diabetes, hypertension, } \\
\text { hyperlipidemia, cardiovascular disease, or rheumatoid arthritis }\end{array}$ \\
\hline $\begin{array}{l}\text { Esposito et al. } \\
{[17], 2006}\end{array}$ & Italy & $\begin{array}{l}\text { Cross-sectional } \\
\text { study }\end{array}$ & $\begin{array}{l}\text { 1,528 Italian men and } 863 \\
\text { women all with psoriasis }\end{array}$ & 2,391 & DSM-IV & $\begin{array}{l}\text { Depressive symptomatology was observed in } 1,482 / 2,391 \text { patients } \\
\text { ( } 62 \% \text { overall; females, } 63 \% \text {; males, } 61 \% \text { ); men }<40 \text { years of age were } \\
\text { significantly more likely to report depressive symptoms than were } \\
\text { men } \geq 40 \text { years of age ( } 67 \text { vs. } 58 \% \text {, respectively, } p=0.002 \text { ) }\end{array}$ \\
\hline $\begin{array}{l}\text { Gupta et al. } \\
{[18], 1989}\end{array}$ & USA & $\begin{array}{l}\text { Cross-sectional } \\
\text { study }\end{array}$ & $\begin{array}{l}64 \text { high-stress reactors and } \\
63 \text { low-stress reactors, all } \\
\text { with psoriasis }\end{array}$ & 127 & DSM-IV & $\begin{array}{l}\text { The high-stress reactors had more disfiguring disease clinically }(\mathrm{p}< \\
0.02) ; \mathrm{psychologically} \text {, they tended to rely more upon the approval of } \\
\text { others }(\mathrm{p}<0.05) \text { and experienced more psoriasis-related daily stress } \\
(\mathrm{p}<0.005) \text {; the high-stress reactors also reported more flare-ups of } \\
\text { their psoriasis during the } 6 \text { months prior to admission }(\mathrm{p}<0.05)\end{array}$ \\
\hline $\begin{array}{l}\text { Gupta et al. } \\
\text { [19], } 1994\end{array}$ & USA & $\begin{array}{l}\text { Cross-sectional } \\
\text { study }\end{array}$ & $\begin{array}{l}\text { Outpatients with } \\
\text { mild-to-moderate psoriasis } \\
(\mathrm{n}=77) \text {, atopic dermatitis } \\
(\mathrm{n}=143) \text {, and chronic } \\
\text { idiopathic urticaria } \\
(\mathrm{n}=32)\end{array}$ & 252 & DSM-IV & $\begin{array}{l}\text { A direct correlation (Pearson's } \mathrm{r}=0.34, \mathrm{p}<0.0001 \text { ) between pruritus } \\
\text { severity and the Carroll Rating Scale for Depression score was obser- } \\
\text { ved; the correlations between pruritus severity and Carroll Rating } \\
\text { Scale for Depression scores for each individual diagnostic group were } \\
\text { as follows: psoriasis: Pearson's } \mathrm{r}=0.32, \mathrm{p}=0.004 \text {; atopic dermatitis: } \\
\text { Pearson's } \mathrm{r}=0.21, \mathrm{p}=0.013 \text {; chronic idiopathic urticaria: Pearson's } \\
\mathrm{r}=0.34, \mathrm{p}=0.06\end{array}$ \\
\hline
\end{tabular}

\begin{tabular}{|c|c|c|c|c|c|}
\hline $\begin{array}{l}\text { Fortune et al. } \\
{[23], 2002}\end{array}$ & USA & $\begin{array}{l}\text { Longitudinal } \\
\text { study }\end{array}$ & $\begin{array}{l}\text { Patients with psoriasis } \\
\text { attending an outpatient } \\
\text { psoriasis specialty clinic } \\
\text { who chose to receive } \\
\text { standard psoriasis } \\
\text { treatment alone }(\mathrm{n}=53) \text { or } \\
\text { to enter the Psoriasis } \\
\text { Symptom Management } \\
\text { Programme as an adjunct } \\
\text { to standard therapy } \\
(\mathrm{n}=40)\end{array}$ & 93 & DSM-IV \\
\hline
\end{tabular}

As compared with standard treatment alone, analysis of covariance indicated that participation in the Psoriasis Symptom Management Programme resulted in a greater reduction in clinical severity of psoriasis $(\mathrm{p}=0.001)$, anxiety $(\mathrm{p}=0.001)$, depression $(\mathrm{p}=0.001)$, psoriasis-related stress $(p=0.001)$, and disability $(p=0.04)$ after 6 weeks and 6 months of follow-up

Uyemura et al. USA Cross-Sectional Biopsies were obtained [31], 1993 Study from both lesional skin and

Unspecified DSM-IV

Psoriatic lesions have a type-1 cytokine profile ( IL-2, IFN- $\gamma$, and TNF- $\alpha$ ), without a significant component of type- 2 cytokines (IL-4, lesion-free skin of individuals with psoriasis and compared to normal skin biopsies from control subjects IL-5, and IL-10), accompanied by aberrant expression of ELAM-1 an VCAM-1 on dermal endothelial cells, and ICAM-1 on epidermal keratinocytes; 4 of 5 lesion-free biopsies from psoriatic patients had prominent cytokine mRNA expression compared with skin from normal donors (particularly TNF- $\alpha$, IL- $1 \alpha$, and IL- $1 \beta$, with lesser increases in IFN- $\gamma$ and granulocyte/macrophage colony-stimulating factor), which was accompanied by aberrant adhesion molecule expression in the same 4 samples

\begin{tabular}{|c|c|c|c|c|c|c|}
\hline $\begin{array}{l}\text { Wong et al. } \\
\text { [37], } 2008\end{array}$ & USA & $\begin{array}{l}\text { Cross-sectional } \\
\text { study }\end{array}$ & $\begin{array}{l}\text { Mexican Americans with } \\
\text { major depressive disorder }\end{array}$ & Unspecified & DSM-IV & $\begin{array}{l}\text { SNPs in } 2 \text { genes critical for T-cell function are associated with } \\
\text { susceptibility to major depressive disorder: PSMB4 (proteasome- } \beta_{4} \\
\text { subunit), important for antigen processing, and TBX21 (T bet), } \\
\text { critical for differentiation; analyses revealed a significant combined } \\
\text { allele dose-effect: individuals who had 1,2, and } 3 \text { risk alleles were } 2.3 \text {, } \\
3.2 \text {, and } 9.8 \text { times more likely to have the diagnosis of major } \\
\text { depressive disorder, respectively; associations of several SNPs and } \\
\text { antidepressant response were also found; those genes support the role } \\
\text { of T-cell (CD3E, PRKCH, PSMD9, and STAT3) and HPA axis } \\
\text { (UCN3) functions in treatment response; in major depressive disorder } \\
\text { there were increased levels of CXCL10/IP-10, which decreased in } \\
\text { response to antidepressants; this further suggests predominance of } \\
\text { type-1 T-cell activity in major depressive disorder }\end{array}$ \\
\hline
\end{tabular}


Table 1 (continued)

\begin{tabular}{|c|c|c|c|c|c|c|}
\hline $\begin{array}{l}\text { Author/ } \\
\text { publication } \\
\text { year }\end{array}$ & Country & $\begin{array}{l}\text { Study } \\
\text { design }\end{array}$ & Population & Sample size & $\begin{array}{l}\text { Diagnostic } \\
\text { criteria }\end{array}$ & Main points \\
\hline $\begin{array}{l}\text { Miller et al. } \\
{[38], 2008}\end{array}$ & USA & Review & N/A & N/A & N/A & $\begin{array}{l}\text { Increased peripheral blood inflammatory biomarkers, including } \\
\text { inflammatory cytokines, are seen in depressive patients }\end{array}$ \\
\hline $\begin{array}{l}\text { Motivala et al. } \\
{[40], 2005}\end{array}$ & USA & $\begin{array}{l}\text { Cross-sectional } \\
\text { study }\end{array}$ & $\begin{array}{l}\text { Patients with acute } \\
\text { DSM-IV major depressive } \\
\text { disorder }(\mathrm{n}=22) \text { and age-, } \\
\text { gender-, and body } \\
\text { weight-matched } \\
\text { comparison controls } \\
(\mathrm{n}=18)\end{array}$ & 40 & DSM-IV & $\begin{array}{l}\text { Compared with matched controls, depressed patients showed } \\
\text { significant }(p<0.05) \text { nocturnal elevations of circulating levels of IL- } 6 \\
\text { and sICAM; both sleep latency and REM density had moderate } \\
\text { correlations with IL- } 6 \text { and sICAM }(r \geq 0.30) \text {; backward regression } \\
\text { analyses indicated that sleep latency }(\beta=0.34, p<0.05) \text { and REM } \\
\text { density }(\beta=0.27, p=0.09) \text { were better predictors of IL- } 6 \text { than } \\
\text { depressive status; similarly, sleep latency }(\beta=0.27, p=0.06) \text { and REM } \\
\text { density }(\beta=0.32, p=0.02) \text { were also better predictors of sICAM }\end{array}$ \\
\hline
\end{tabular}

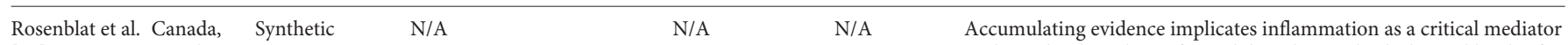

[41], $2014 \quad$ Brazil review in the pathophysiology of mood disorders; indeed, elevated levels of
proinflammatory cytokines have been repeatedly demonstrated in both major depressive disorder and bipolar disorder patients; further, the induction of a proinflammatory state in healthy or medically ill subjects induces 'sickness behavior' resembling depressive symptomatology; potential mechanisms involved include, but are not limited to, direct effects of proinflammatory cytokines on monoamine levels, dysregulation of the HPA axis, pathological microglial cell activation, impaired neuroplasticity, and structural and functional brain changes

\begin{tabular}{|c|c|c|c|c|c|c|}
\hline $\begin{array}{l}\text { McNally et al. } \\
{[42], 2008}\end{array}$ & USA & $\begin{array}{l}\text { Systematic } \\
\text { review }\end{array}$ & N/A & N/A & N/A & $\begin{array}{l}\text { Multiple lines of evidence suggest that inflammation and glutamate } \\
\text { dysfunction contribute to the pathophysiology of depression; in this } \\
\text { review an overview of how these } 2 \text { systems may interact is provided; } \\
\text { excess levels of inflammatory mediators occur in a subgroup of } \\
\text { depressed patients; studies of acute experimental activation of the } \\
\text { immune system with endotoxin and of chronic activation during } \\
\text { IFN-a treatment show that inflammation can cause depression; } \\
\text { peripheral inflammation leads to microglial activation which could } \\
\text { interfere with excitatory amino acid metabolism leading to } \\
\text { inappropriate glutamate receptor activation; loss of astroglia, a feature } \\
\text { of depression, upsets the balance of anti- and proinflammatory } \\
\text { mediators and further impairs the removal of excitatory amino acids; } \\
\text { microglia activated by excess inflammation, astroglial loss, and } \\
\text { inappropriate glutamate receptor activation ultimately disrupt the } \\
\text { delicate balance of neuroprotective versus neurotoxic effects in the } \\
\text { brain, potentially leading to depression }\end{array}$ \\
\hline
\end{tabular}

Moon et al. UK Systematic N/A N/A Activation of neurohormones by stress is predominantly via the HPA

[43], 2013 review axis with upregulation of CRH, adrenocorticotrophic hormone, and
glucocorticoids, alongside neuropeptide stress response mediators; the immune system is profoundly altered: glucocorticoids inhibit IL-12, IFN- $\gamma$, and TNF via antigen-presenting cells and Th1 cells. IL-4, IL-10, and IL-13 are upregulated via Th2 cells; cortisol exerts an immunosuppressive effect shifting Th1 to Th2-mediated immunity; $\mathrm{CRH}$ also directly affects localized inflammatory responses; skin has a fully functional peripheral HPA axis that translates and coordinates the peripheral stress response from the central HPA axis, creating its own cutaneous homeostasis; neuropeptides, substance P and nerve growth factor facilitate communication between neuronal and immune cells and promote migration of macrophages and monocytes through vascular endothelium; the cutaneous immune system may also regulate the central nervous system; mast-cell histamine increase the expression of CRH messenger RNA in the hypothalamus of dogs, and IL-1 and IL-6 (elevated in psoriasis) trigger CRH release; furthermore, proinflammatory cytokines can induce sickness behavior and depressive symptoms

\begin{tabular}{|c|c|c|c|c|c|c|}
\hline $\begin{array}{l}\text { Maes et al. } \\
{[70], 2011}\end{array}$ & Thailand & $\begin{array}{l}\text { Systematic } \\
\text { review }\end{array}$ & N/A & N/A & N/A & $\begin{array}{l}\text { This review gives an explanation for the multiple 'comorbidities' } \\
\text { between depression and a large variety of brain disorders related to } \\
\text { neurodegeneration (e.g. Alzheimer's, Parkinson's and Huntington's } \\
\text { disease, multiple sclerosis, and stroke), medical disorders (such as } \\
\text { cardiovascular disorder, chronic fatigue syndrome, chronic } \\
\text { obstructive pulmonary disease, rheumatoid arthritis, psoriasis, } \\
\text { systemic lupus erythematosus, inflammatory bowel disease, irritable } \\
\text { bowel syndrome, leaky gut, diabetes type } 1 \text { and 2, obesity and the } \\
\text { metabolic syndrome, and HIV infection), and conditions such as } \\
\text { hemodialysis, IFN- } a \text {-based immunotherapy, the postnatal period, and } \\
\text { psychosocial stressors; the common denominator of all those } \\
\text { disorders/conditions is the presence of microglial activation and/or } \\
\text { activation of peripheral oxidative and nitrosative stress pathways }\end{array}$ \\
\hline
\end{tabular}


Table 1 (continued)

\begin{tabular}{|c|c|c|c|c|c|c|}
\hline $\begin{array}{l}\text { Author/ } \\
\text { publication } \\
\text { year }\end{array}$ & Country & $\begin{array}{l}\text { Study } \\
\text { design }\end{array}$ & Population & Sample size & $\begin{array}{l}\text { Diagnostic } \\
\text { criteria }\end{array}$ & Main points \\
\hline $\begin{array}{l}\text { Devrimci- } \\
\text { Ozguven et al. } \\
{[72], 2000}\end{array}$ & USA & $\begin{array}{l}\text { Cross-sectional } \\
\text { study }\end{array}$ & Psoriasis patients & 50 & DSM-IV & $\begin{array}{l}34 \text { patients declared that they had had a psychologically stressful life } \\
\text { event in the last } 3 \text { months prior to the beginning of the illness; the } \\
\text { mean PASI score was } 1.75 \pm 1.65 \text {, BDI score } 13.58 \pm 6.11 \text {, STAI-I score } \\
39.54 \pm 9.18 \text {, STAI-II score } 46.58 \pm 8.05 \text {, LSS score } 9.18 \pm 4.39 \text {, CECS } \\
\text { score } 51.64 \pm 9.75 \text {, and BIS score } 93.74 \pm 16.67\end{array}$ \\
\hline
\end{tabular}

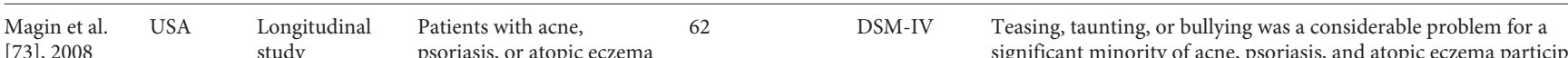
psoriasis, or atopic eczema significant minority of acne, psoriasis, and atopic eczema participants; recruited from both themes that emerged were the universally negative nature of the specialist dermatology and general practices teasing, the use of teasing as an instrument of social exclusion and as a means of establishing or enforcing power relationships, teasing related to contagion and fear, the emotional and psychological sequelae of teasing, and the theme of 'insensate' teasing; for those who had suffered teasing or bullying, this was causally linked in respondents' accounts with psychological sequelae, especially self-consciousness and effects on self-image and self-esteem; experiences of teasing and bullying were found to have principally occurred during the adolescence of participants, and the perpetrators were other adolescents, but there were findings of respondents with psoriasis also having been subjected to ridicule or derogatory remarks by health professionals; teasing, taunting, and bullying may represent an underappreciated source of psychological morbidity in children and adolescents with these common skin diseases

\begin{tabular}{lllll}
\hline $\begin{array}{l}\text { Kartha et al. } \\
\text { [79], India } 2014\end{array}$ & $\begin{array}{l}\text { Cross-sectional } \\
\text { study }\end{array}$ & $\begin{array}{l}36 \text { psoriasis cases and 36 } \\
\text { age- and gender-matched } \\
\text { healthy controls }\end{array}$ & 72 & DSM-IV \\
& & &
\end{tabular}

Nighttime levels of melatonin levels in serum showed a significant decline in psoriasis cases compared with controls; melatonin is antiinflammatory in nature, and low levels contribute to pruritus which may cause koebnerization and further aggravation of psoriasis; modulation of melatonin secretion may be a possible alternate mechanism by which methoxypsoralens and phototherapy help in the management of psoriasis and associated depression; recent reports suggest that antidepressants such as agomelatine, a new melatonergic agonist, attenuates the inflammatory changes in depression by reducing the release of the proinflammatory cytokines from activated microglia, which correlates with an improvement in monoamine neurotransmitter function; this may open up possibilities for a new generation of antidepressants in the future for the management of depression, a major comorbidity in patients with psoriasis

\begin{tabular}{|c|c|c|c|c|c|c|}
\hline $\begin{array}{l}\text { Carrillo- } \\
\text { Vico et al. } \\
{[81], 2013}\end{array}$ & Spain & $\begin{array}{l}\text { Systematic } \\
\text { review }\end{array}$ & N/A & N/A & N/A & $\begin{array}{l}\text { Melatonin modulates a wide range of physiological functions with } \\
\text { pleiotropic effects on the immune system; despite the large number of } \\
\text { reports implicating melatonin as an immunomodulatory compound, } \\
\text { it still remains unclear how melatonin regulates immunity; while } \\
\text { some authors argue that melatonin is an immunostimulant, many } \\
\text { studies have also described anti-inflammatory properties; the data } \\
\text { reviewed in this paper support the idea of melatonin as an immune } \\
\text { buffer, acting as a stimulant under basal or immunosuppressive } \\
\text { conditions or as an anti-inflammatory compound in the presence of } \\
\text { exacerbated immune responses such as acute inflammation }\end{array}$ \\
\hline $\begin{array}{l}\text { Esposito } \\
\text { and Cuzzocrea } \\
{[82], 2010}\end{array}$ & Italy & $\begin{array}{l}\text { Systematic } \\
\text { review }\end{array}$ & N/A & N/A & N/A & $\begin{array}{l}\text { Melatonin reduces chronic and acute inflammation; the } \\
\text { immunomodulatory properties of melatonin are well known; it acts } \\
\text { on the immune system by regulating cytokine production of } \\
\text { immunocompetent cells; experimental and clinical data shows that } \\
\text { melatonin reduces adhesion molecules and proinflammatory } \\
\text { cytokines and modifies serum inflammatory parameters; melatonin } \\
\text { improves the clinical course of illnesses which have an inflammatory } \\
\text { etiology; moreover, experimental evidence supports its actions as a } \\
\text { direct and indirect antioxidant, scavenging free radicals, stimulating } \\
\text { antioxidant enzymes, enhancing the activities of other antioxidants, or } \\
\text { protecting other antioxidant enzymes from oxidative damage; several } \\
\text { encouraging clinical studies suggest that melatonin is a } \\
\text { neuroprotective molecule in neurodegenerative disorders where brain } \\
\text { oxidative damage has been implicated as a common link }\end{array}$ \\
\hline $\begin{array}{l}\text { Kannan et al. } \\
\text { [87], } 2013\end{array}$ & USA & Review & N/A & N/A & N/A & $\begin{array}{l}\text { TNF- } \alpha \text { antagonists, frequently used in the treatment of psoriasis, may } \\
\text { be helpful in directly reducing depressive symptoms for patients with } \\
\text { psoriasis and other chronic inflammatory conditions }\end{array}$ \\
\hline
\end{tabular}


Table 2. The changes in inflammatory markers involved in psoriasis and depression

\begin{tabular}{|c|c|}
\hline Inflammatory markers in psoriasis & Inflammatory markers in depression \\
\hline - BDNF levels are decreased & - BDNF levels are decreased \\
\hline $\begin{array}{l}\text { - Increased levels of T cells, dendritic cells, and } \\
\text { inflammatory cytokines, including TNF- } \alpha \text {, IL-1, } \\
\text { IL-6, IL-2, and IFN- } \gamma\end{array}$ & $\begin{array}{l}\text { - Elevation in the concentration of proinflammatory } \\
\text { cytokines, including prostaglandin E2, CRP, } \\
\text { TNF- } \alpha \text {, IL-1 } \beta, \text { IL-2, and IL-6 }\end{array}$ \\
\hline $\begin{array}{l}\text { - Mutations in the regulatory cytokine IL-10 or } \\
\text { defects in surrounding regulatory T cells }\end{array}$ & $\begin{array}{l}\text { - Increased levels of CXCL10/IP-10, which } \\
\text { decreased in response to antidepressants }\end{array}$ \\
\hline $\begin{array}{l}\text { - Presence of inflammatory cytokines such as TNF- } \alpha \text {, } \\
\text { IFN- } \gamma \text {, and other type- } 1 \text { cytokines }\end{array}$ & $\begin{array}{l}\text { - Increased levels of peripheral blood inflammatory } \\
\text { biomarkers, including inflammatory cytokines }\end{array}$ \\
\hline $\begin{array}{l}\text { - Abnormally low melatonin levels and decreased } \\
\text { neurotransmitter response }\end{array}$ & - Diminished melatonin secretion \\
\hline $\begin{array}{l}\text { - Raised percentage of CD2+, CD4+, and CD8+ } \\
\text { lymphocytes and reduced percentage of CD4+ } \\
\text { lymphocytes in comparison with controls; } \\
\text { remarkably high CD4/CD8 ratio }\end{array}$ & $\begin{array}{l}\text { - Raised percentage of CD2+, CD4+, and CD8+ } \\
\text { lymphocytes and reduced percentage of CD4+ } \\
\text { lymphocytes in comparison with controls; } \\
\text { remarkably high CD4/CD8 ratio }\end{array}$ \\
\hline $\begin{array}{l}\text { - Increased serotonin transporter activity and } \\
\text { function }\end{array}$ & $\begin{array}{l}\text { - Greater 5-HTT availability and increased levels of } \\
\text { downstream proinflammatory cytokines, especially } \\
\text { TNF- } \alpha \text { and IL-6 }\end{array}$ \\
\hline
\end{tabular}

this relationship is bidirectional. Depression and psoriasis are more than coincidental comorbidities of each other, and in many cases psoriasis severity is strongly associated with an increase in depressive symptoms and vice versa. Major depression itself is a disorder that is often poorly characterized and not well defined in a majority of psoriasis and depression studies, and therefore there is an incredible amount of missing data as to what proportion of psoriasis patients may actually be suffering from major depressive disorder, potentially leading to smaller observed numbers. Depression and psoriasis have been hypothesized to be linked through inflammatory mechanisms, and this paper supports that hypothesis. Depression has been found to increase the concentration of proinflammatory cytokines systemically in patients afflicted with the disease, and these same proinflammatory cytokines migrate towards the epidermis and cause psoriatic lesions in susceptible patients, either increasing psoriasis severity or potentially leading to its outbreak. On the other hand, mutations in genes related to psoriasis cause an increase in the same proinflammatory cytokines. These cytokines can cause HPA axis hyperactivity observed in major depressive disorder and disturb the negative feedback inhibition of circulating corticosteroids on the said axis and lead to lower serotonergic (5-HT) neurotransmitter levels, thus leading to depressive disorder.
In addition, circulating melatonin levels are known to be increasingly low in both psoriasis and depression patients, more so in patients with both conditions, and regulating melatonin levels have shown an effect on reducing the clinical severity of both conditions simultaneously. Thus, we believe that in the near future this melatonin level could also be used globally as a marker for depression-induced psoriasis until the mystery of the psoriasis caused by the depression neurochemicals is totally resolved. As of now, we believe that depression leads to psoriasis by a pathophysiological phenomenon which needs more understanding in the near future, especially due to the fact that certain biomarkers present after inflammation in depression are not present in psoriasis and vice versa. As such, antidepressant therapy may be effective in reducing psoriasis severity, psoriasis treatment may also have an effect on a patient's depressive symptoms, and phototherapy may be a potent treatment for both. However, we believe that the above evidence is still inconclusive about why not all depressed patients acquire psoriasis and why not all psoriasis patients acquire depression. We believe future studies dealing with the neuroimmunology of major depression will be able to unearth this association in detail and help future scientists in exploring the detailed mechanism of how major depression induces psoriasis through a neurochemical phenomenon. 


\section{Acknowledgment}

The authors are grateful for the help, guidance, and support of Nobel Prize-nominated professor Dr. Howard I. Maibach (University of California, San Francisco).

\section{Disclosure Statement}

The authors declare no conflicts of interest. There was no financial support for this work.

\section{Statement of Ethics}

thors.

All ethical standards were followed and maintained by the au-

\section{References}

1 Levenson, James L: Essentials of Psychosomatic Medicine. Arlington, American Psychiatric Press, 2006.

-2 Brown GE, Malakouti M, Sorenson E, Gupta R, Koo JY: Psychodermatology. Adv Psychosom Med 2015;34:123-134.

3 Leon A, Levin EC, Koo JY: Psychodermatology: an overview. Semin Cutan Med Surg 2013;32:64-67.

4 Questions and Answers about Psoriasis. National Institute of Arthritis and Musculoskeletal and Skin Diseases. October 2013. http:// www.niams.nih.gov/health_info/psoriasis/.

5 Menter A, Gottlieb A, Feldman SR, Van Voorhees AS, Leonardi CL, Gordon KB, Lebwohl M, Koo JY, Elmets CA, Korman NJ Beutner KR, Bhushan R: Guidelines of care for the management of psoriasis and psoriatic arthritis. Section 1. Overview of psoriasis and guidelines of care for the treatment of psoriasis with biologics. J Am Acad Dermatol 2008; 58:826-850.

6 Lebwohl M: Psoriasis. Lancet 2003;361:11971204.

7 Chong HT, Kopecki Z, Cowin AJ: Lifting the silver flakes: the pathogenesis and management of chronic plaque psoriasis. Biomed Res Int 2013;2013:168321.

-8 Huerta C, Rivero E, Garcia Rodriguez LA: Incidence and risk factors for psoriasis in the general population. Arch Dermatol 2007;143 1559-1565.

-9 Parisi R, Symmons DP, Griffiths CE, Ashcroft DM; Identification and Management of Psoriasis and Associated Comorbidity (IMPACT) project team: Global epidemiology of psoriasis: a systematic review of incidence and prevalence. J Invest Dermatol 2013;133:377385.

10 Krishnadas R, Nicol A, Sassarini J, Puri N, Burden AD, Leman J, Combet E, Pimlott $S$, Hadley D, McInnes IB, Cavanagh J: Circulating tumour necrosis factor is highly correlated with brainstem serotonin transporter availability in humans. Brain Behav Immun 2016;51:29-38.
11 White JR, Chang CH, So-Armah KA, Stewart JC, Gupta SK, Butt AA, Gibert CL, Rimland $\mathrm{D}$, Rodriguez-Barradas MC, Leaf DA, Bedimo RJ, Gottdiener JS, Kop WJ, Gottlieb SS, Budoff MJ, Khambaty T, Tindle H, Justice AC, Freiberg MS: Depression and HIV Infection are Risk Factors for Incident Heart Failure Among Veterans: Veterans Aging Cohort Study. Circulation 2015;132:1630-1638.

12 Bisschop MI, Kriegsman DM, Deeg DJ, Beekman AT, van Tilburg W: The longitudinal relation between chronic diseases and depression in older persons in the community: the Longitudinal Aging Study Amsterdam. J Clin Epidemiol 2004;57:187-194.

13 Krishnan KR, Delong M, Kraemer H, Carney R, Spiegel D, Gordon C, McDonald W, Dew M, Alexopoulos G, Buckwalter K, Cohen PD, Evans D, Kaufmann PG, Olin J, Otey E, Wainscott C: Comorbidity of depression with other medical diseases in the elderly. Biol Psychiatry 2002;52:559-588.

14 Nicholson A, Kuper H, Hemingway H: Depression as an aetiologic and prognostic factor in coronary heart disease: a meta-analysis of 6,362 events among 146,583 participants in 54 observational studies. Eur Heart J 2006;27: 2763-2774.

15 Nasir U, Shahid H, Shabbir MO: Sleep quality and depression in hospitalized congestive heart failure patients. J Pak Med Assoc 2015; 65:264-269.

16 Akay A, Pekcanlar A, Bozdag KE, Altintas L, Karaman A: Assessment of depression in subjects with psoriasis vulgaris and lichen planus. J Eur Acad Dermatol Venereol 2002;16:347352.

17 Esposito M, Saraceno R, Giunta A, Maccarone $\mathrm{M}$, Chimenti S: An Italian study on psoriasis and depression. Dermatology 2006;212: 123-127.

-18 Gupta MA, Gupta AK, Kirkby S, Schork NJ, Gorr SK, Ellis CN, Voorhees JJ: A psychocutaneous profile of psoriasis patients who are stress reactors. A study of 127 patients. Gen Hosp Psychiatry 1989;11:166-173.
19 Gupta MA, Gupta AK, Schork NJ, Ellis CN: Depression modulates pruritus perception: a study of pruritus in psoriasis, atopic dermatitis, and chronic idiopathic urticaria. Psychosom Med 1994;56:36-40.

20 Fordham B, Griffiths CE, Bundy C: A pilot study examining mindfulness-based cognitive therapy in psoriasis. Psychol Health Med 2015;20:121-127.

21 Polenghi MM, Molinari E, Gala C, Guzzi R, Garutti C, Finzi AF: Experience with psoriasis in a psychosomatic dermatology clinic. Acta Derm Venereol Suppl (Stockh) 1994;186:6566.

22 Menter A, Augustin M, Signorovitch J, Yu AP, Wu EQ, Gupta SR, Bao Y, Mulani P: The effect of adalimumab on reducing depression symptoms in patients with moderate to severe psoriasis: a randomized clinical trial. J Am Acad Dermatol 2010;62:812-818.

23 Fortune DG, Richards HL, Kirby B, Bowcock S, Main CJ, Griffiths CE: A cognitive-behavioural symptom management programme as an adjunct in psoriasis therapy. Br J Dermatol 2002;146:458-465.

24 Mease PI, Signorovitch J, Yu AP, Wu EQ Gupta SR, Bao Y, Mulani PM: Impact of adalimumab on symptoms of psoriatic arthritis in patients with moderate to severe psoriasis: a pooled analysis of randomized clinical trials. Dermatology 2010;220:1-7.

-25 Redighieri IP, Maia Tde C, Nadal MA, Caliman TR, Ruiz Mde F, Petri V: Erythrodermic psoriasis with regression after prophylaxis with isoniazid and antidepressant therapy: case report. An Bras Dermatol 2011;86(4 sup$\mathrm{pl} 1): S 141-S 143$

26 Van Voorhees AS, Fried R: Depression and quality of life in psoriasis. Postgrad Med 2009; 121:154-161.

27 Palfreeman AC, McNamee KE, McCann FE: New developments in the management of psoriasis and psoriatic arthritis: a focus on apremilast. Drug Des Devel Ther 2013;7:201210 
28 Cedeno-Laurent F, Gómez-Flores M, Mendez N, Ancer-Rodríguez J, Bryant JL, Gaspari AA, Trujillo JR: New insights into HIV-1 primary skin disorders. J Int AIDS Soc 2011;14:5.

29 Nestle FO, Kaplan DH, Barker J: Psoriasis. N Engl J Med 2009;361:496-509.

-30 Ouyang W: Distinct roles of IL-22 in human psoriasis and inflammatory bowel disease. Cytokine Growth Factor Rev 2010;21:435441.

-31 Uyemura K, Yamamura M, Fivenson DF, Modlin RL, Nickoloff BJ: The cytokine network in lesional and lesion-free psoriatic skin is characterized by a T-helper type 1 cell-mediated response. J Invest Dermatol 1993;101: 701-715.

- 32 Raychaudhuri SK, Maverakis E, Raychaudhuri SP: Diagnosis and classification of psoriasis. Autoimmun Rev 2014;13:490-495.

- 33 Parrish L: Psoriasis: symptoms, treatments and its impact on quality of life. Br J Community Nurs 2012;17:524, 526, 528.

- 34 Brunoni AR, Lotufo PA, Sabbag C, Goulart AC, Santos IS, Benseñor IM: Decreased brainderived neurotrophic factor plasma levels in psoriasis patients. Braz J Med Biol Res 2015; 48:711-714.

- 35 Kim J, Bissonnette R, Lee J, Correa da Rosa J, Suárez-Fariñas M, Lowes MA, Krueger JG: The spectrum of mild-to-severe psoriasis vulgaris is defined by a common activation of IL17 pathway genes, but with key differences in immune regulatory genes. J Invest Dermatol 2016, DOI: 10.1016/j.jid.2016.04.032, Epub ahead of print.

-36 Speeckaert R, Lambert J, Grine L, Van Gele M, De Schepper S, van Geel N: The many faces of IL-17 in inflammatory skin diseases. Br J Dermatol 2016, DOI: 10.1111/bjd.14703, Epub ahead of print.

- 37 Wong ML, Dong C, Maestre-Mesa J, Licinio $\mathrm{J}$ : Polymorphisms in inflammation-related genes are associated with susceptibility to major depression and antidepressant response. Mol Psychiatry 2008;13:800-812.

- 38 Miller AH, Maletic V, Raison CL: Inflammation and its discontents: the role of cytokines in the pathophysiology of major depression. Biol Psychiatry 2008;65:732-741.

- 39 Miller AH, Raison CL: Immune system contributions to the pathophysiology of depression. Focus (Am Psychiatr Publ) 2008;6:3645.

-40 Motivala SJ, Sarfatti A, Olmos L, Irwin MR: Inflammatory markers and sleep disturbance in major depression. Psychosom Med 2005 67:187-194.

41 Rosenblat JD, Cha DS, Mansur RB, McIntyre RS: Inflamed moods: a review of the interactions between inflammation and mood disorders. Prog Neuropsychopharmacol Biol Psychiatry 2014;53:23-34.

42 McNally L, Bhagwagar Z, Hannestad J: Inflammation, glutamate, and glia in depression: a literature review. CNS Spectr 2008; 13 : 501-510.
43 Moon H, Mizara A, McBride SR: Psoriasis and psycho-dermatology. Dermatol Ther (Heidelb) 2013;3:117-130.

44 Kannan S, Heller MM, Lee ES, Koo JY: The role of tumor necrosis factor- $\alpha$ and other cytokines in depression: what dermatologists should know. J Dermatolog Treat 2013;24: 148-152.

45 Alesci S, Martinez PE, Kelkar S, Ilias I, Ronsaville DS, Listwak SJ, Ayala AR, Licinio J, Gold HK, Kling MA, Chrousos GP, Gold PW: Major depression is associated with significant diurnal elevations in plasma interleukin-6 levels, a shift of its circadian rhythm, and loss of physiological complexity in its secretion: clinical implications. J Clin Endocrinol Metab 2005;90:2522-2530.

- 46 Miller GE, Stetler CA, Carney RM, Freedland KE, Banks WA: Clinical depression and inflammatory risk markers for coronary heart disease. Am J Cardiol 2002;90:1279-1283.

-47 Bouhuys AL, Flentge F, Oldehinkel AJ, van den Berg MD: Potential psychosocial mechanisms linking depression to immune function in elderly subjects. Psychiatry Res 2004;127: 237-245.

48 Musselman DL, Miller AH, Porter MR, Manatunga $\mathrm{A}, \mathrm{Gao} F$, Penna S, Pearce BD, Landry J, Glover S, McDaniel JS, Nemeroff CB: Higher than normal plasma interleukin- 6 concentrations in cancer patients with depression: preliminary findings. Am J Psychiatry 2001; 158:1252-1257.

49 Kahl KG, Rudolf S, Stoeckelhuber BM, Dibbelt L, Gehl HB, Markhof K, Hohagen F, Schweiger U: Bone mineral density, markers of bone turnover, and cytokines in young women with borderline personality disorder with and without comorbid major depressive disorder. Am J Psychiatry 2005;162:168-174.

50 Tiemeier H, Hofman A, van Tuijl HR, Kiliaan AJ, Meijer J, Breteler MM: Inflammatory proteins and depression in the elderly. Epidemiology 2003;14:103-107.

51 Schlatter J, Ortuño F, Cervera-Enguix S: Monocytic parameters in patients with dysthymia versus major depression. J Affect Disord 2004;78:243-247.

52 Ford DE, Erlinger TP: Depression and C-reactive protein in US adults. Arch Intern Med 2004;164:1010-1014.

53 Danner M, Kasl SV, Abramson JL, Vaccarino V: Association between depression and elevated C-reactive protein. Psychosom Med 2003;65:347-356.

54 Maes M: Major depression and activation of the inflammatory response system. Adv Exp Med Biol 1999;461:25-46.

55 Levine J, Barak Y, Chengappa KN, Rapoport A, Rebey M, Barak V: Cerebrospinal cytokine levels in patients with acute depression. Neuropsychobiology 1999;40:171-176.

56 Lanquillon S, Krieg JC, Bening-Abu-Shach $\mathrm{U}$, Vedder $\mathrm{H}$ : Cytokine production and treatment response in major depressive disorder. Neuropsychopharmacology 2000;22:370379.
57 Rajagopalan S, Brook R, Rubenfire M, Pitt E, Young E, Pitt B: Abnormal brachial artery flow-mediated vasodilation in young adults with major depression. Am J Cardiol 2001;88: 196-198.

58 Sluzewska A, Rybakowski JK, Laciak M, Mackiewicz A, Sobieska M, Wiktorowicz $\mathrm{K}$ : Interleukin- 6 serum levels in depressed patients before and after treatment with fluoxetine. Ann NY Acad Sci 1995;762:474-476.

59 Maes M, Bosmans E, De Jongh R, Kenis G, Vandoolaeghe E, Neels H: Increased serum IL-6 and IL-1 receptor antagonist concentrations in major depression and treatment resistant depression. Cytokine 1997;9:853-858.

-60 Mikova O, Yakimova R, Bosmans E, Kenis G, Maes M: Increased serum tumor necrosis factor alpha concentrations in major depression and multiple sclerosis. Eur Neuropsychopharmacol 2001;11:203-208.

-61 Sluzewska A, Sobieska M, Rybakowski JK Changes in acute-phase proteins during lithium potentiation of antidepressants in refractory depression. Neuropsychobiology 1997; 35:123-127.

62 Tuglu C, Kara SH, Caliyurt O, Vardar E, Abay E: Increased serum tumor necrosis factora levels and treatment response in major depressive disorder. Psychopharmacology (Berl) 2003;170:429-433.

63 Hestad KA, Tønseth S, Støen CD, Ueland T, Aukrust P: Raised plasma levels of tumor necrosis factor alpha in patients with depression. J ECT 2003;19:183-188.

64 Owen BM, Eccleston D, Ferrier IN, Young AH: Raised levels of plasma interleukin-1beta in major and postviral depression. Acta Psychiatr Scand 2001;103:226-228.

65 Thomas AJ, Davis S, Morris C, Jackson E, Harrison R, O'Brien JT: Increase in interleukin-1 $\beta$ in late-life depression. Am J Psychiatry 2005;162:175-177.

66 Raison CL, Capuron L, Miller AH: Cytokines sing the blues: inflammation and the pathogenesis of depression. Trends Immunol 2006; 27:24-31.

67 Beretta L, Cossu M, Marchini M, Cappiello F, Artoni A, Motta G, Scorza R: A polymorphism in the human serotonin 5-HT2A receptor gene may protect against systemic sclerosis by reducing platelet aggregation. Arthritis Res Ther 2008;10:R103.

$68 \mathrm{Ni}$, Chiu MW: Psoriasis and comorbidities: links and risks. Clin Cosmet Investig Dermatol 2014;7:119-132.

69 Schiepers OJ, Wichers MC, Maes M: Cytokines and major depression. Prog Neuropsychopharmacol Biol Psychiatry 2005;29:201217.

70 Maes M, Kubera M, Obuchowiczwa E, Goehler L, Brzeszcz J: Depression's multiple comorbidities explained by (neuro)inflammatory and oxidative and nitrosative stress pathways. Neuro Endocrinol Lett 2011;32:724.
Psychopathophysiology of DepressionInduced Psoriasis and Vice Versa
Skin Pharmacol Physiol 2016;29:220-230 DOI: $10.1159 / 000448122$ 
71 Al'Abadie MS, Kent GG, Gawkrodger DJ: The relationship between stress and the onset and exacerbation of psoriasis and other skin conditions. Br J Dermatol 1994;130:199-203.

72 Devrimci-Ozguven H, Kundakci TN, Kumbasar H, Boyvat A: The depression, anxiety, life satisfaction and affective expression levels in psoriasis patients. J Eur Acad Dermatol Venereol 2000;14:267-271

73 Magin P, Adams J, Heading G, Pond D, Smith $\mathrm{W}$ : Experiences of appearance-related teasing and bullying in skin diseases and their psychological sequelae: results of a qualitative study. Scand J Caring Sci 2008;22:430-436.

-74 Fava GA, Perini GI, Santonastaso P, Fornasa $\mathrm{CV}$ : Life events and psychological distress in dermatologic disorders: psoriasis, chronic urticaria and fungal infections. Br J Med Psychol 1980;53:277-282.

-75 Gupta MA, Schork NJ, Gupta AK, Kirkby $\mathrm{S}$, Ellis CN: Suicidal ideation in psoriasis. Int J Dermatol 1993;32:188-190.

76 Hardy GE, Cotterill JA: A study of depression and obsessionality in dysmorphophobic and psoriatic patients. Br J Psychiatry 1982;140: 19-22.
Breuer K, Göldner FM, Jäger B, Werfel T, Schmid-Ott G: Relationship between chronic stress and CRP levels in women with psoriasis. J Dtsch Dermatol Ges 2016;14:528-530.

78 Schmid-Ott G, Jaeger B, Boehm T, Langer K, Stephan M, Raap U, Werfel T: Immunological effects of stress in psoriasis. Br J Dermatol 2009;160:782-785.

79 Kartha LB, Chandrashekar L, Rajappa M, Menon $\mathrm{V}$, Thappa DM, Ananthanarayanan $\mathrm{PH}$ : Serum melatonin levels in psoriasis and associated depressive symptoms. Clin Chem Lab Med 2014;52:1-3.

80 Sandyk R, Pardeshi R: Mood-dependent fluctuations in the severity of tardive dyskinesia and psoriasis vulgaris in a patient with schizoaffective disorder: possible role of melatonin. Int J Neurosci 1990;50:215-221.

-81 Carrillo-Vico A, Lardone PJ, Alvarez-Sánchez N, Rodríguez-Rodríguez A, Guerrero JM: Melatonin: buffering the immune system. Int J Mol Sci 2013;14:8638-8683.

82 Esposito E, Cuzzocrea S: Anti-inflammatory activity of melatonin in central nervous system. Curr Neuropharmacol 2010;8:228-242.

83 Mozzanica N, Tadini G, Radaelli A, Negri M, Pigatto P, Morelli M, Frigerio U, Finzi A, Esposti G, Rossi D, et al: Plasma melatonin levels in psoriasis. Acta Derm Venereol 1988; 68:312-316.
84 Diffey BL: Ultraviolet radiation physics and the skin. Phys Med Biol 1980;25:405-426.

-85 Golpour M, Hosseini SH, Khademloo M, Ghasemi M, Ebadi A, Koohkan F, Shahmohammadi S: Depression and anxiety disorders among patients with psoriasis: a hospitalbased case-control study. Dermatol Res Pract 2012;2012:381905.

86 Dalgard FJ, Gieler U, Tomas-Aragones L, Lien L, Poot F, Jemec GB, Misery L, Szabo C, Linder D, Sampogna F, Evers AW, Halvorsen JA, Balieva F, Szepietowski J, Romanov D, Marron SE, Altunay IK, Finlay AY, Salek SS, Kupfer J: The psychological burden of skin diseases: a cross-sectional multicenter study among dermatological out-patients in $13 \mathrm{Eu}$ ropean countries. J Invest Dermatol 2015;135: 984-991.

87 Demirhan O, Demirbek B, Tunç E, Uslu IN, Çetiner S, Serin A: Identification of chromosome abnormalities in screening of a family with manic depression and psoriasis: predisposition to aneuploidy. Asian J Psychiatr 2012;5:169-174. 


\section{Erratum}

In the article by Tohid et al. entitled 'Major depression and psoriasis: a psychodermatological phenomenon' [Skin Pharmacol Physiol 2016;29:220-230, DOI: 10.1159/ 000448122], the following article carrying very interesting information about the pathophysiological association of major depression with psoriasis should also have been cited:

Connor CJ, Liu V, Fiedorowicz JG: Exploring the Physiological Link between Psoriasis and Mood Disorders. Dermatol Res Pract 2015;2015:409637, DOI: 10.1155/2015/409637. Epub October 15, 2015. https://www.hindawi.com/journals/drp/2015/409637/. 